\title{
E-Banking and Commercial Bank Performance in Nigeria: A Cointegration and Causality Approach
}

\author{
Amu Christian Ugwueze*, Nathaniel. C. Nwezeaku \\ Department of Financial Management Technology, Federal University of Technology, Owerrii, Nigeria. \\ * Corresponding author. Email: chrisuamu@ yahoo.com \\ Manuscript submitted October 9, 2015; accepted April 29, 2016. \\ doi: 10.17706/ijeeee.2016.6.3.175-185
}

\begin{abstract}
This work studied the relationship between electronic banking and the performance of Nigerian commercial banks. The study became necessary due to the increased adoption of the electronic banking which has redefined the banking service both in Nigeria and internationally. Electronic banking was proxied by value of Point-of-Sale transactions while commercial banking performance was proxied by customers' deposits. Engle-Granger cointegration model was used to analyse data for the sample period January 2009 to December 2013. The results show that POS is not cointegrated with both the savings and time deposits but are cointegrated with demand deposits. It is recommended that the monetary authorities and commercial banks should embark on an all inclusive enlightenment campaign for the banking public on the benefits, convenience and importance of adopting e-banking channels in completing their transactions.
\end{abstract}

Key words: Electronic banking, performance, Nigerian commercial banks, cointegration, point-of-sale.

\section{Introduction}

Today's banking environment is very dynamic and undergoes rapid changes as a result of innovations in information and communication technology (ICT), increased awareness and demand from customers. Banking industry of the $21^{\text {st }}$ century operates in a complex and competitive environment characterized by these changing conditions and highly unpredictable economic climate. ICT is at the centre of this global change curve. ICT has changed the dimensions of competition in the retail banking sector. Ref. [1] for example, concludes that the automated teller machine (ATM), Point of Sale (PoS) terminals and Internet services are the major instruments used by the customers of the deposit money banks in Nigeria. Following the introduction of electronic banking and internet automated teller machines (ATMs) which are the initial cornerstones of electronic finance, the increased adoption and penetration of mobile banking and Internet banking has added a new distribution channel to retail banking: Internet/Online-banking.

The quest for banks in Nigeria to have efficient customer service delivery and maintain global relevance in the system has led to the exploitation of the many advantages of ICT through the use of automated devices imperative in the industry. Many studies have also been conducted to establish the relevance of ICT to commercial bank performance.

Another motivation for the numerous studies on e-banking is customer satisfaction. Customer satisfaction holds the potential for increasing an organization customer base, increase the use of more volatile customer mix and increase the firm's reputation. Consequently, obtaining competitive advantage is secured through intelligent identification and satisfaction of customers' needs better and sooner than 
competitions and sustenance of customer's satisfaction through better products/services. A satisfied customer will definitely continue his patronage but unsatisfied customer will withdraw his patronage. There is need to provide evidence on the extent to which ICT operations have impacted on customer service delivery in Nigeria deposit banks.

The Central Bank of Nigeria (CBN) has in recent times engaged in series of reformations aimed at both making the Nigerian financial system formidable and enhancing the overall economic performance of Nigeria so as to place it on the right path in tune with global trends. One of the major reforms is the Cashless Policy. The cashless policy is a new policy on cash-based transactions which stipulates a 'cash handling charge' on daily cash withdrawals or cash deposits that exceed N500,000 for Individuals and N3,000,000 for Corporate bodies. The policy aims at reducing not eliminating the amount of physical cash circulating in the economy, and encouraging more electronic-based transactions in Nigeria [2].

Ref. [3] observes that good as it may be made to look; the system will come at some costs. As noted above, the use of POS terminals in the cashless system will attract special charges that do not go with cash transactions. A price tag of $1.25 \%$ of the cost of every transaction done through POS terminals will be charged by the operators of the terminals [4]. This may be considered over-burdensome on the banking public given that this will not obviate nor lessen the normal commission on turnover charged by banks on withdrawals. Apart from being an additional charge on bank customers, the charges appear to be too high. Normal bank commission on turnover is 5 for every 1000 representing $0.05 \%$ of the amount of such transactions, compared to the CBN approved charges of $1.25 \%$ which would means 12.50 for every 1000 .

There is need therefore to ascertain the relationship betweene-banking and commercial bank performance in Nigeria.

\subsection{Objectives of the Study}

The main objective of the study is to examine relationship between e-banking activities (proxied by value of POS transactions) and the performance of commercial banks in Nigeria (proxied by customers' deposit). Specifically, the study strives to achieve the following objectives:

1) To determine the relationship between POS transactionsandcustomers' savings deposits in commercial banks in Nigeria.

2) To examine the relationship between POS transactions and customers' time deposits in commercial banks in Nigeria.

3) To analyse the relationship between POS transactions and customers' demand deposits in commercial banks in Nigeria.

\section{Theoretical Framework and Empirical Literature}

\subsection{Theoretical Framework}

\subsubsection{The cashless system - An overview}

Contrary to what is suggestive of the term, cashless economy does not refer to an outright absence of cash transactions in the economic setting but one in which the amount of cash-based transactions are kept to the barest minimum. It is an economic system in which transactions are not done predominantly in exchange for actual cash. It is not also an economic system where goods and services are exchanged for goods and service (the barter system). It is an economic setting in which goods and services are bought and paid for through electronic media. It is defined as "one in which there are assumed to be no transactions frictions that can be reduced through the use of money balances, and that accordingly provide a reason for holding such balances even when they earn rate of return [5]. Ref. [6] observes that in a cashless economy, how much cash in your wallet is practically irrelevant. You can pay for your purchases by any one of a plethora of 
credit cards or bank transfer. In Nigeria, under the cashless economy concept, the goal is to discourage cash transactions as much as possible. The CBN had set daily cumulative withdrawal and deposit limits of $\mathrm{N} 150,000$ for individuals and N1,000,000 for corporate entities (now reviewed to N500,000 and N3million respectively). Penalty fees of $\mathrm{N} 100$ and $\mathrm{N} 200$ respectively (now reduced to $5 \%$ and $3 \%$ respectively) are to be charged per extra N1000 [7].

It should be said that as at now there are already some forms of cashless transactions that are taking place in Nigeria. It is noted that: Today there are up to seven different electronic payment channels in Nigeria, Automated Teller Machines (ATM), points of sales terminals, mobile voice, web, inter-bank branch and kiosks. E-payment initiatives in Nigeria have been undertaken by indigenous firms and have been stimulated by improvement in technology and infrastructure [8].

As noted above, the cashless economy does not imply an outright end to the circulation of cash (or money) in the economy but that of the operation of a banking system that keeps cash transactions to the barest minimum. The CBN had set daily limits of cumulative withdraws and lodgments of 150, 000 for individuals and 1,000,000 for corporate customers (now 500,000 and 3million respectively). The operation of the system does not mean the individual/corporations cannot hold cash in excess of 150,000/ N1million (now $500,000 / \mathrm{N} 3$ million) respectively at any single point in time but that their cumulative cash transactions with the bank must not exceed these limits over a period of one day. The system is targeted at encouraging electronic means of making payments, and not aimed at discouraging cash holdings. This policy on limits implies that an individual can actually have 5,000,000 (more than 150,000 now 500,000) under his pillow at home, buys goods and services with them but must not pay more than 500,000 into his bank in one day without attracting a fine of $5 \%$ per 1000 for the excess. What is anticipated by this policy is that instead of making large withdrawals to effect payment for goods and services, such monies will be kept in the banking system so that payments are made through "debit/credit card-like means."

\subsubsection{The POS - An overview}

In this system users are issued with electronic cards which can be slotted into special electronic machines in order to effect payments. At the centre of such payment system are the Point of Sales (POS) terminals [9]. These are to be deployed across commercial points in the country. These POS terminals thus deployed will serve like the Automatic Teller Machines (ATM). In this case, upon completing a transaction and the value ascertained, the amount is entered into a POS terminal into which the electronic card has been slotted. The cash equivalent of the amount is transferred from the payer's account into the account of the payee automatically [10]. Users are issued with a card (the electronic purse). The electronic purse is topped up using revaluation terminals. There are different types of terminals: coin \& note, credit card and payroll deduction terminals. The cards are simply inserted into the revaluation terminal and certain programmed instructions are followed, and money is added onto the electronic purse. This can then be used to pay for goods/services by inserting them into the POS terminals. When the card is inserted into the POS, and the transaction amount entered, the reader reads the amount and is quickly deducted from the e-purse (the card).

It has to be noted that the operation of the cashless economy (electronic payment) system is not entirely free. Curiously, using the POS comes with a hefty price tag of 1.25 percent of the cost of every purchase or transaction that is effected in addition to the 5 for every 1000 Commission on Turnover that our deposit money banks are allowed by CBN to charge every time money is taken from our account [4].

\subsubsection{Benefits of e-banking}

Experts have pointed out specific areas in which the e-banking will enhance the quality of life. These include:

1) Faster transactions - reducing queues at points of sales 
2) Improving hygiene on site - eliminating the bacterial spread through handling notes and coins.

3) Increased sales

4) Cash collection made simple - time spent on collecting, counting and sorting cash eliminated

5) Managing staff entitlements

It is also noted that:

It reduces transfer/processing fees, increases processing transaction time, offers multiple payment options and gives immediate notification on all transactions on customers' account.

It is also beneficial to the banks and merchants; (there) are large customer coverage, international products and services, promotion and branding, increase in customer satisfaction and personalized relationship with customers, and easier documentation and transaction tracking [11]

As a policy instrument, CBN has heaped a lot of praises on the cashless system. CBN has hinged economic development on the cashless system; it sees it as a tool for tackling corruption and money laundering. It has been pointed out that: "Among the reasons glibly advanced by the CBN for this policy include reducing the cost of cash management, making the Nigerian economy cashless, checking money laundering and the insecurity of cash in transit. Statistics show that cash management in 2009 cost N114.5 billion and this is projected to stand at $\mathrm{N} 200$ billion in 2020. In the same vein, the cashless system provides the opportunity of being able to "follow the money" and thus check money laundering across boarders. Added to this is the perceived impact on the Naira. The system will reduce the pressure on the Naira. This can only happen if there is effective and standard cross-boarder electronic transmittal's reporting system. Following from the above therefore, it is anticipated that the cashless system will bring with it transparency in business transactions [12]. In the same token, the cashless economy will bring with it a leaning towards banking culture. It is seen that the effort is directed at "... ensuring 'cashless economy' and nurturing the culture of saving in the unbanked majority in the country" [13]. Most of Nigerians are still unbanked, and so we have large proportion of the citizenry not subject to such monetary policy instruments as are used in the banking system. This development will make CBN's policy tools more effective for achieving economic development and stability goals.

It appears that the most serious appeal of the cashless system comes from the high cost of cash management in Nigeria [14]. Other identified reasons for the cashless economy policy are robbering, revenue leakages and inefficient treasury. The system will present some costs to the banking public, there will be some costs to be borne by government and there will be costs for the operators of the system.

\subsubsection{Challenges of e-banking in Nigeria}

Commercial banks in Nigeria offer a wide variety of services on the internet. Some of the obvious challenges to an effective banking service delivery in Nigeria include but not limited to the following:

1) There is no proper infrastructural development for performing e-banking activities in Nigeria.

2) Slow uptake of internet access and PCS due to high level of illiteracy among Nigerians

3) There is poor telecommunication network policies and slow paced regulatory initiatives.

4) There are very few users of internet facilities across the country.

5) The banking infrastructure in terms of electronic payments and inter-bank connectivity is poor

6) There is no effective legal system to encourage e-banking activities in Nigeria

7) There is lack of skilled and efficient IT workforce

8) Cyber laws to prosecute cybercrimes are not in place

9) ATMs may have network problems, unavailability and shortage of money as experienced in most ATMs across the country.

10) The price of computer, computer hardware, banking software and their maintenance are expressive.

Ref. [15] reviewed the state of e-banking implementation in Nigeria and evaluate the influence of trust on 
the adoption of e-payment using an extended technology acceptance model. The findings in this work reveal that perceived ease and perceived usefulness are not only antecedent to e-banking acceptance. Also, [16] reviewed electronic banking products and performance of Nigerian listed deposit money banks. Ref. [17] investigated the impact of electronic banking on profitability of commercial banks in Nigeria using secondary data extracted from the Nigerian Stock Exchange Factbook for the period 1997 to 2010. They found that the adoption of electronic banking has positively and significantly improved the returns on equity of Nigerian banks. They recommend that the banking industry should adjust to full and effective deployment of ICT due to its sophistication and perceived advantages.

Ref. [18] examine the impact of electronic banking on the Jordanian banks' performance. Empirical analysis has been conducted on a panel data of 15 Jordanian banks for the period 2000-2010. Accounting data were used to measure the banks' performance and regressed on relevant variables using OLS regression. The results show that electronic banking has a significant negative impact on banks' performance. Electronic banking has not improved the performance of these banks. Banks' customers in Jordan depend on traditional channels to carry out their banking operations. As a result, costs associated with adopting electronic banking are still higher than revenues from provision of electronic services. They recommend that banks should focus its work to promote the confidence of electronic banking services and encourage the customers to use this kind of services.

Ref. [19] opine that the proliferation and penetration of internet has opened new horizons and scenarios for the retail banking industry. The retail banks are now providing their products and services through the electronic medium; e-banking. E-banking is considered to have a substantial impact on banks' performance. Hence, they examine the impact of e-banking on the profitability of Pakistani banks, in particular using qualitative method on data from twelve banks across Pakistan. The results show that e-banking has increased the profitability of banks; it has enabled the banks to meet their costs and earn profits even in the short span of time. The illiteracy of customers is not regarded as a major impediment in provision of their products and services. For banks, the main motive to adopt e-banking is to increase their clientage and to retain their customers. The profitability of banks has augmented in transitioning to e-banking medium.

Ref. [20] investigate the relationship between e-banking and performance of Kenya banking system. Specifically, the study was set to establish whether there is relationship between the dependent variable i.e., performance measured by return on assets and the independent variables: investments in e-banking, number of ATMS and number of debits cards issued to customers as proxy for e-banking. The study used both descriptive and inferential statistics in analyzing the data. In general the study revealed that e-banking has strong and significance marginal effects on returns on asset in the Kenyan banking industry. Thus, there exists positive relationship between e-banking and bank performance. They conclude that electronic banking has made banking transaction to be easier by bringing services closer to its customers hence improving banking industry performance.

Ref. [21] study the impact of cashless policy in Nigeria using survey research with questionnaire as data collection instrument. Responses from the respondents show that cashless policy will increase employment reduce cash related robbery thereby reducing risk of carrying cash; cashless policy will also reduce cash related corruption and attract more foreign investors to the country. The study, therefore, shows that the introduction of cashless economy in Nigeria can be seen as a step in the right direction. It is expected that its impact will be felt in modernization of Nigeria payment system, reduction in the cost of banking services, reduction in high security and safety risks and also curb banking related corruptions.

Ref. [1] examine the impact of automated teller machine (ATM), point of sales (PoS), Mobile and Internet service values on the intermediation efficiency of the Nigerian economy using multiple regression technique on time series data of 2006 - 2011. The study reports the following findings: that there is 
significant relationship between ATM, PoS, Internet service values and the intermediation efficiency of the Nigerian economy. However, the study also reveals that there is no significant relationship between Mobile service value and intermediation efficiency of the Nigerian economy within the period under study. He concludes that the ATM, PoS and Internet services are the major instruments used by the customers of the deposit money banks in Nigeria, and recommends that the banks should put more effort in advertising these products in Nigeria.

\section{Methodology}

\subsection{Model Specification}

To investigate the relationship between e-banking and commercial bank performance in Nigeria, we employ the following mode

$$
\begin{gathered}
B D=f\left(P O S_{t}\right) \\
B D_{t}=\beta_{0}+\beta_{1} P O S_{t}+\mu_{t}
\end{gathered}
$$

The a priori expectation of the slope coefficient is: $P O S>0$.

where $B D t$ is the dependent variable and is the observations of monthly commercial bank deposits, $P O S_{t}$ denotes the monthly observations of the value of POS transactions, $\beta_{1}$ is the coefficient and its effect on real bank deposit and $\mu_{\mathrm{t}}$ is the stochastic error term at time $t$.

\subsection{Description of Data}

The data for this study are monthly series of savings deposit, time deposits, demand deposit, and monthly value of POS transactions in Nigeria. The series were obtained from Central Bank of Nigeria (CBN) statistical bulletin for various years. The sample period under consideration for the variables ranges from January 2009 to December 2013.

\subsection{Techniques of Analysis}

The technique of analysis of the relationship between b-banking and commercial bank performance in Nigeria is the Engel-Granger cointegration model. Basically, in cointegration method, even though two time series may not themselves be stationary, a linear combination of the two non-stationary time series may be stationary. If this is the case, the two original non-stationary time series are said to be 'cointegrated'. Usually, for cointegration, the two time series have to be stationary after the same number of differencing. If a given time series becomes stationary after first differencing, it is said to be integrated of order one $I(1)$. If the time series becomes stationary after second differencing, it is integrated of order two I(2). If the original time series is stationary, it is integrated of order zero $I(0)$. When a linear combination of two $I(1)$ series is stationary, then the two time series are cointegrated. Cointegration implies a long-run relationship between them.

To check for the order of integration we estimate the Augmented Dickey-Fuller (ADF) (1981) test for unit roots. The ADF is generally regarded as the most efficient test from among the simple tests for integration and is at present the most widely used in practice.

After determining the order of integration, the next step is to estimate the cointegrating regression equation as stated in Equation (1), and then test if the residuals $\mu_{\mathrm{t}}$ are stationary. We can test whether the bank deposits and POS are cointegrated by testing whether the residuals $\mu_{t}$ are stationary. Since we cannot observe $\mu_{\mathrm{t}}$, we instead test the stationarity of the least squares residuals using a Dickey-Fuller test. We estimate the residual-based unit root test thus: 


$$
\Delta \mu_{t}=\alpha_{1} \mu_{t-1}+\varepsilon_{t}
$$

where $\Delta \mu_{t}$ is the first difference of $\mu_{t}$, and examine the $t(\operatorname{tau})$ statistic for the estimated slope $(\alpha)$. Because we are basing this test upon estimated values, to test the hypothesis of a unit root, we estimate by least squares and examine the $t$-statistic for the hypothesis that $\alpha=0$. The $\mathrm{t}$-statistic must be compared to critical values taken from Davidson and Mackinnon (1993) in [22]. If the tau statistic is less than the critical value at $5 \%$ level of significance, we reject the null hypothesis that the least squares residuals are nonstationary, and conclude that they are stationary. Thus we conclude that the variables are cointegrated, indicating that there is a long-run, equilibrium relationship between the variables.

\section{Empirical Findings and Discussions}

\subsection{Descriptive Statistics}

Table 1 shows descriptive statistics of the growth series of savings deposits, time deposits, demand deposits, and monthly value of POS transactions in Nigeria for the sample period. Notice that value of POS transactions has the highest average growth rate but time deposit has the least growth rate. Also the value of POS transactions has the highest standard deviation but savings deposit has the least. The value of POS transactions is negatively skewed with fat-tails but the commercial bank deposits are normally distributed.

Table 1. Descriptive Statistics

\begin{tabular}{|c|c|c|c|c|c|}
\hline & Mean & Standard Deviation & skewness & Kutorsis & J-B. Stat. \\
\hline GVPOS & 0.0482 & 0.6959 & $\begin{array}{l}-4.2541 \\
(0.000)\end{array}$ & $\begin{array}{c}33.2943 \\
(0.000)\end{array}$ & $\begin{array}{r}2903.05 \\
(0.000)\end{array}$ \\
\hline GSD & 0.0133 & 0.0238 & $\begin{array}{l}0.0508 \\
(0.876)\end{array}$ & $\begin{array}{l}0.1559 \\
(0.817)\end{array}$ & $\begin{array}{l}0.0852 \\
(0.958)\end{array}$ \\
\hline GTD & 0.0036 & 0.1287 & $\begin{array}{l}-0.4753 \\
(0.146)\end{array}$ & $\begin{array}{c}19.7428 \\
(0.000)\end{array}$ & $\begin{array}{l}960.42 \\
(0.000)\end{array}$ \\
\hline GDD & 0.0041 & 0.0458 & $\begin{array}{l}0.1324 \\
(0.685)\end{array}$ & $\begin{array}{l}0.3980 \\
(0.556)\end{array}$ & $\begin{array}{l}0.5620 \\
(0.755)\end{array}$ \\
\hline
\end{tabular}

Note: GSD, GTD and GDD are the growth rates of savings deposits, time deposits, and demand deposits respectively. (.) is the $p$-value.

\subsection{Unit Root Test}

Table 2 presents the results of unit root tests performed on levels and growth series of savings deposits, time deposits, demand deposits, and monthly value of POS transactions in Nigeria for the sample period. Notice from Table 2 that log of POS does not contain unit root but log of bank deposits all have unit root. Note however that the growth series of all the variables do not contain unit roots.

Table 2. Unit Root Test Result

\begin{tabular}{|cccccc|}
\hline & \multicolumn{2}{c}{ Log-level Series } & \multicolumn{3}{c|}{ Computed $t$} \\
\hline LVPOS & -3.4848 & $-4.1034 * *$ & DVPOS & -2.9117 & $-7.2801^{* * *}$ \\
\hline LSD & -3.4848 & -1.5930 & DSD & -2.9127 & $-3.6917 * * *$ \\
\hline LTD & -3.4875 & -2.3956 & DTD & -2.9117 & $-7.5098^{* * *}$ \\
\hline LDD & -3.4848 & $-3.1823^{*}$ & DDD & -2.9109 & $-8.2960^{* * *}$ \\
\hline
\end{tabular}

\subsection{Testing the Long-Run Relationship}

This section presents the results of the relationship expressed in equation (1). Panel A, B and C of Table 3 show the estimates of the cointegrating regression and Engle-Granger cointegration tests between savings deposit and value of POS transactions, time deposit and value of POS transactions, and demand deposit and 
value of POS transactions. Notice from Panel $A$ of Table 4that POS do not have long-run relationship with private sector savings deposits at $5 \%$ significance level. This is evident in the larger absolute value of $5 \%$ critical tau $(-3.942)$ than the computed tau value $(-1.840)$. Given that the $5 \%$ critical tau is greater in absolute value than our computed tau value, at all conventional significance levels, we accept the null hypothesis of no cointegration between POS and savings deposit in Nigeria.Similarly, POS do not have long-run relationship with private sector time deposits. It is clear from Pane $\mathrm{C}$ of Table 3 , however, that we cannot reject cointegration (i.e. long-run relation) between POS and demand deposits. The residual-based unit root test results show that the computed tau ( $r$ ) statistic $\left(-3.995^{* *}\right)$ is greater than the $5 \%$ critical tau $(r)$ value $(-3.942)$ in absolute value. Since the computed $r$ value is greater than the conventional critical tau in absolute value, we reject the null hypothesis of no cointegration. This result, therefore, indicate evidence of long-term relationship between POS and demand deposit in Nigeria.

Table 3. Cointegration Test Results

\begin{tabular}{|c|c|c|c|c|}
\hline Panel A & \multicolumn{4}{|c|}{ Relationship between POS and Savings Deposits } \\
\hline & Variable & Coefficients & $t$-Stat & Significance \\
\hline & LVPOS & -0.024 & -2.494 & 0.016 \\
\hline & Constant & 13.857 & 876.783 & 0.000 \\
\hline & Trend & 0.0149 & 23.372 & 0.000 \\
\hline & \multicolumn{4}{|c|}{ Engle-Granger Cointegration Test } \\
\hline & $5 \%$ Critical & $t$-Stat & & \\
\hline & -3.942 & -1.840 & & \\
\hline \multirow[t]{8}{*}{ Panel A } & \multicolumn{4}{|c|}{ Relationship between POS and Time Deposits } \\
\hline & Variable & Coefficients & T-Stat & Significance \\
\hline & LNPOS & 0.074 & 3.652 & 0.000 \\
\hline & Constant & 0.000 & 56.507 & 0.000 \\
\hline & Trend & -0.0006 & -0.304 & 0.762 \\
\hline & \multicolumn{4}{|c|}{ Engle-Granger Cointegration Test } \\
\hline & $5 \%$ Critical & T-Stat & & \\
\hline & -3.439 & -3.227 & & \\
\hline \multirow[t]{8}{*}{ Panel A } & \multicolumn{4}{|c|}{ Relationship between POS and Demand Deposits } \\
\hline & Variable & Coefficients & T-Stat & Significance \\
\hline & LNPOS & -0.0306 & -2.778 & 0.007 \\
\hline & Constant & 14.852 & 809.6 & 0.000 \\
\hline & Trend & 0.008 & 10.939 & 0.000 \\
\hline & \multicolumn{4}{|c|}{ Engle-Granger Cointegration Test } \\
\hline & $5 \%$ Critical & T-Stat & & \\
\hline & -3.942 & $-3.995 * *$ & & \\
\hline
\end{tabular}

Granger Causality Test Results

Granger causality test was estimated to examine whether causality runs from e-banking, proxied by the value of point of sale transaction, to commercial banking performance in Nigeria, proxied by private sector savings, time, and demand deposits. Results of the Granger causality test are shown in Tables 1 and 2 . Notice from Panel A in both tables 1 and 2 that there is no causality from e-banking to private sector savings deposit at the 10\% percent significance level. From Panel B of Tables 1 and 2, there is evidence of bidirectional causality between e-banking and private sector savings deposit at the $1 \%$ percent significance level. Panel $\mathrm{C}$ of Tables 1 and 2 shows evidence of unidirectional causality from private sector demand deposit to e-banking at the $5 \%$ percent significance level. The lag lengths were chosen using Akaike Information Criterion (AIC). 
Table 4. Granger Causality Result from e-Banking to Commercial Bank Performance

\begin{tabular}{|c|c|c|c|}
\hline \multicolumn{4}{|c|}{ GVPOS $\rightarrow$ GPSD } \\
\hline & Coefficients & $p$-value & Lags \\
\hline $\mathbf{F}((\mathbf{2 , 5 2 )}$ & 2.554 & 0.087 & 1 to 2 \\
\hline \multicolumn{4}{|c|}{ GVPOS $\rightarrow$ GPTD } \\
\hline & Coefficients & $p$-value & Lags \\
\hline $\mathbf{F}(2,52)$ & 7.595 & 0.001 & 1 to 2 \\
\hline \multicolumn{4}{|c|}{ GVPOS $\rightarrow$ GPDD } \\
\hline & Coefficients & $p$-value & Lags \\
\hline$F(2,52)$ & 0.467 & 0.629 & 1 to 2 \\
\hline
\end{tabular}

Note: $\rightarrow$ indicate the direction of causality.

Table 5. Granger Causality Result from Commercial Bank Performance to e-Banking

\begin{tabular}{|c|c|c|c|}
\hline \multicolumn{4}{|c|}{ GPSD $\rightarrow$ GVPOS } \\
\hline & Coefficients & $p$-value & Lags \\
\hline$F(2,52)$ & 1.215 & 0.304 & 1 to 2 \\
\hline \multicolumn{4}{|c|}{ GPTD $\rightarrow$ GVPOS } \\
\hline & Coefficients & $p$-value & Lags \\
\hline$F(2,52)$ & 100.968 & 0.000 & 1 to 2 \\
\hline \multicolumn{4}{|c|}{ GPDD $\rightarrow$ GVPOS } \\
\hline & Coefficients & $p$-value & Lags \\
\hline$F(2,52)$ & 3.733 & 0.030 & 1 to 2 \\
\hline
\end{tabular}

\section{Conclusions and Recommendation}

The major objective of this paper is to analyse the relationship between the e-banking (proxied by value of Point-of-Sale Terminal transactions) and commercial bank performance (proxied by savings, time, and demand deposits) in Nigeria using the Engle-Granger two steps cointegration method. The ADF unit root test shows that the e-banking is integrated of order zero $(I(0))$ whereas commercial bank performance are integrated of order one (I(1)). The estimates of the Engle-Grangercointegration tests show that POS is not cointegrated with both the savings and time deposits but are cointegrated with demand deposits. We conclude that a long-run run relationship between POS and demand deposits in Nigeria.

It is recommended that the monetary authorities and commercial bank enlighten their customer on the convenience and importance of adopting e-banking channels in completing their transactions.

\section{References}

[1] Okoro, A. S. (2014), Impact of electronic banking instruments on the intermediation efficiency of the Nigerian economy. International Journal of Accounting Research, 1(6), 14-21.

[2] Central Bank of Nigeria. (2012). New cash policy, presentation for the interactive engagement session with stakeholders on cash-less Lagos, stakeholder session-supermarket operators.

[3] Oyewole, O. S., Abba, M., El-Maude, J. G., \& Arikpo, I. A. (2013). E-banking and bank performance: Evidence from Nigeria. International Journal of Scientific Engineering and Technology, 2(8), 766-771.

[4] Omose, K. (2011). Deconstructing CBN cashless policy. Retrieved from the website: http://www.mobilemoneyafrica.com/

[5] Woodford, M. (2003). Interest \& Price: Foundation of a Theory of Monetary Policy. Princeton: University Press.

[6] Omotunde, M., Sunday, T., \& John-Dewole, A. T. (2013). Impact of cashless economy in Nigeria. Greener Journal of Internet, Information and Communication Systems, 1(2), 040-043. 
[7] Ezumba, S. (2011). The Transition to a Cashless Nigeria. Reinventing Rebuilding LLC.

[8] Babalola, R. (2008). E-payment: Towards a cashless economy. Proceedings of a Keynote Address of the Finance Minister of State at Card Expo Africa Conference.

[9] Azeez, K. (2011). Fresh hurdles for CBN cashless economy plan.

[10] Olaegbe, R. (2011). Road to Cashless Lagos.

[11] Moses-Ashike, H. (2011). Cashless economic can reduce risk of carrying huge cash. Retrieved from the website: http:// www.businessdayonline.com/.../22217

[12] Jaiyeola, L. (2011). Benefits of cashless economy by experts. Retrieved from the website: http://www.iq4news.com

[13] Nonor, D. (2011). Ghana: Airtel leads drive towards 'cashless economy'. The Chronicle.

[14] Eboh, M. (2011). Cashless economic policy will save Nigeria N192bn-CBN. Retrieved from the website: http://www.Nigerianewsday.com

[15] Ovia, J. (2001). Internet banking: Practice and potentials in Nigeria.

[16] Hassan, S. U., Mamman, A., \& Farouk, M. A. (2013). Electronic banking products and performance of Nigerian listed deposit money banks. American Journal of Computer Technology and Application, 1(10), 138-148.

[17] Abaenewe, Z. C., Ogbulu, O. M., \& Ndugbu, M. O. (2013). Electronic banking and bank performance in Nigeria. West African Journal of Industrial \& Academic Research, 1, 171-186.

[18] Mohammad O. A., \& Saad, A. A. (2011). The impact of e-banking on the performance of Jordanian banks. Journal of Internet banking and Commerce, 16(2), 1-10.

[19] Sumra, S. H., \& Manzoor, M. K. (2011). The impact of e-banking on the profitability of banks: A study of Pakistani banks. Journal of Public Administration and Governance, 1(1), 31-38.

[20] Aduda, J., \& Kingoo, N. (2012). The relationship between electronic banking and financial performance among commercial banks in Kenya. Journal of Finance and Investment Analysis, 1(3), 99-118.

[21] Omotunde, M., Sunday, T., \& John-Dewole, A. T. (2013). Impact of cashless economy in Nigeria. Greener Journal of Internet, Information and Communication Systems, 1(2), 040-043.

[22] Woodford, M. (2003). Interest \& Price: Foundation of a Theory of Monetary Policy. Princeton: University Press.

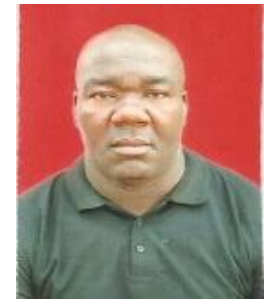

Christian Ugwueze Amu was born on the $15^{\text {th }}$ of April, 1971 in Lejja Nsukka Local Government Area of Enugu State Nigeria. He obtained his B.Sc in accountancy from the Imo State University, Owerri in 2005 and the M.Sc in financial management technology in 2011 from the Federal University of Technology, Owerri. Currently he is a doctoral research student of the Federal University of Technology, Owerri with research interest on "Impact of public debt on economies of less developed countries: Evidence from Nigeria". He has been promoted to the rank of lecturer II. He has attended many conferences, seminars and workshops and has published many articles in local and international scholarly and referred journals in various subjects with special interest in accounting finance and management. He is an associate member, Institute of Chartered Accountants of Nigeria (ICAN).

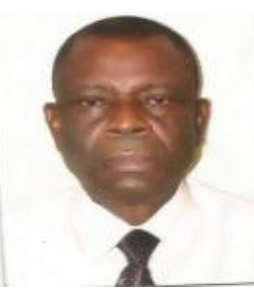

Nathaniel Chinedum Nwezeaku was born on the 24th of May 1958 in Nenu Obingwa Local Government area of Abia State Nigeria. He obtained his B.Sc from the University of Benin in 1983 and the MBA in199l from the Federal University of Technology Owerri where he also obtained his Ph.D in banking and finance in 2002. He was promoted professor of banking and finance in 2010. He has had more than 18 years of University 
Teaching and research experience and he is the author of the books. Theories and Principles of Financial Management and 'Taxation in Nigeria principles and practice' and other books and articles in local and international scholarly a d referred journals in various subjects with special reference to finance, banking, accounting and management. He was the pioneer head of department of Financial Management Technology at the Federal University of Technology Owerri.

Prof. Nwezeaku, a member of the University senate has held many reputable positions and chaired many panels and committees. He is a recipient of many awards, Member and Fellow of many academic institutes and organizations including Fellow of the Chartered Institute of Taxation of Nigeria and Fellow of the International Academy of Business and Behavioral Sciences. He has supervised many Ph.Dthesis, and a member of the National Universities Commission panel on accreditation of Universities and their programs in Management sciences. He is currently the Director, Centre for Entrepreneurial Studies. 